\title{
Prenatal diagnosis of caudal regression syndrome without maternal diabetes mellitus
}

\author{
Maternal diabetes mellitusun eşlik etmediği kaudal regresyon sendromunun prenatal tanısı
}

\author{
Ahmet Özgür Yeniel, Ahmet Mete Ergenoğlu, Sermet Sağol \\ Department of Obstetrics and Gyneocology, Faculty of Medicine, Ege University, Izmir, Turkey
}

\section{Abstract}

Caudal regression syndrome is a rare congenital malformation with varying degrees of early gestational developmental failure. It is also known as sacral agenesis or caudal dysplasia. The cause of this malformation is thought to be defects in neuralization around the 28 th day of the gestational period. Although maternal uncontrolled diabetes, genetic predisposition and vascular hypoperfusion are the possible risk factors, actual pathogenesis is unclear. CRS is generally diagnosed at prenatal assessment, but also a varying number of newborns with some degree of anomaly may be presented. In our case, we diagnosed a caudal regression syndrome fetus early in the second trimester. Determination of the pathology early in the gestational age gives parents a chance for termination of pregnancy. Although diabetes mellitus is the major risk factor for CRS, as in our case, sporadic presentations may occur. So clinicians should consider CRS when CRL is shorter than expected and incomplete vertebral ossification is observed both in gray scala and 3D imaging ultrasonography.

(J Turkish-German Gynecol Assoc 2011; 12: 186-8)

Key words: Caudal regression syndrome, sirenomelia, diabetes mellitus, vertebral anomaly,3D ultrasonography

Received: 18 April, 2010

Accepted: 3 September, 2010

\section{Özet}

Kaudal regresyon sendromu (KRS) çeşitli derecelerde erken gestasyonel gelişim bozukluğunun gözlendiği nadir bir konjenital anomalidir. Bu durum sakral agensesis ya da kaudal displazi olarak da bilinmektedir. Gebeliğin 28. günü civarında oluşabilecek nöralizasyon defekti bu malformasyonun nedeni olarak düşünülmektedir. Maternal kontrolsüz diabet, genetik yatkınlı ve vasküler hipoperfüzyon olası risk faktörleri olmasına rağmen, gerçek patogenezis belirsizdir. KRS tanısı genellikle prenatal olarak koyulur, ancak yine de değişen sayıda yeni doğan çeşitli derecelerde anomalilerle tanı alabilirler. Sunulan kaudal regresyon sendromlu fetüs olgusuna erken ikinci trimesterde tanı koyduk. Patolojinin erken gebelik haftalarında belirlenmesi ile aile gebelik terminasyonu şansına sahip olabilir. Diabetes mellitus, KRS için majör faktörü olmasına karşın, bizim olgumuzda olduğu gibi spoaradik durumlar da sözkonusu olabilir. Böylece, klinisyenler beklenenden kısa CRL ile karşılaştıklarında ve hem gri skala hem de 3D ultrasonografide tamamlanmamış vertebral ossifikasyon görünümü saptadıklarında kaudal regresyon sendromunu düşünmelidir.

(J Turkish-German Gynecol Assoc 2011; 12: 186-8)

Anahtar kelimeler: Kaudal regresyon sendromu, sirenomelia, diabetes mellitus, vertebral anomali, 3D ultrasonografi

Geliş Tarihi: 18 Nisan 2010

Kabul Tarihi: 03 Eylül 2010

\section{Introduction}

Caudal regression syndrome is a congenital malformation with varying degrees of early gestational developmental failure. It is also known as sacral agenesis or caudal dysplasia. These defects may include thoracic, lumbar, coccygeal vertebrae and lower extremities. The cause of this malformation is thought to be defects in neuralization around the 28th day of the gestational period (1). This results in motor and sensory deficits of the lower extremities. Cardiac diseases, gastrointestinal disorders, neutral tube defects, and genitourinary malformations may accompany CRS (2). Although uncontrolled maternal diabetes, genetic predisposition and vascular hypoperfusion are the possible risk factors, the actual pathogenesis is unclear (3).CRS is generally diagnosed during prenatal assessment, but also a varying number of newborns with some degree of anomaly may be presented.
Although the number of pregnancies complicated with caudal regression syndrome is 0,1 to 0,25 per 10000 pregnancies, this ratio increases to $1 \%$ of pregnancies when complicated with diabetes mellitus (DM) (4). DM is a major risk factor for CRS. The fetuses of insulin dependent diabetic mothers have 200 to 400 times more risk for CRS compared to those of non diabetic mothers (3-6).

\section{Case}

A twenty-five year old patient of 16 weeks gravida I, parity was 0 referred to our clinic for vertebral anomaly. In the parental history of the fetus, the couple were infertile for 5 years and pregnancy was achieved by intracytoplasmic sperm injection. Also, the couple had rh incompatibility, the mother's blood being B Rh(-) and the father's $0 \mathrm{Rh}(+)$. Except for these issues, the patient's history was unremarkable. Biochemical and hematological parameters were all within the normal range. 

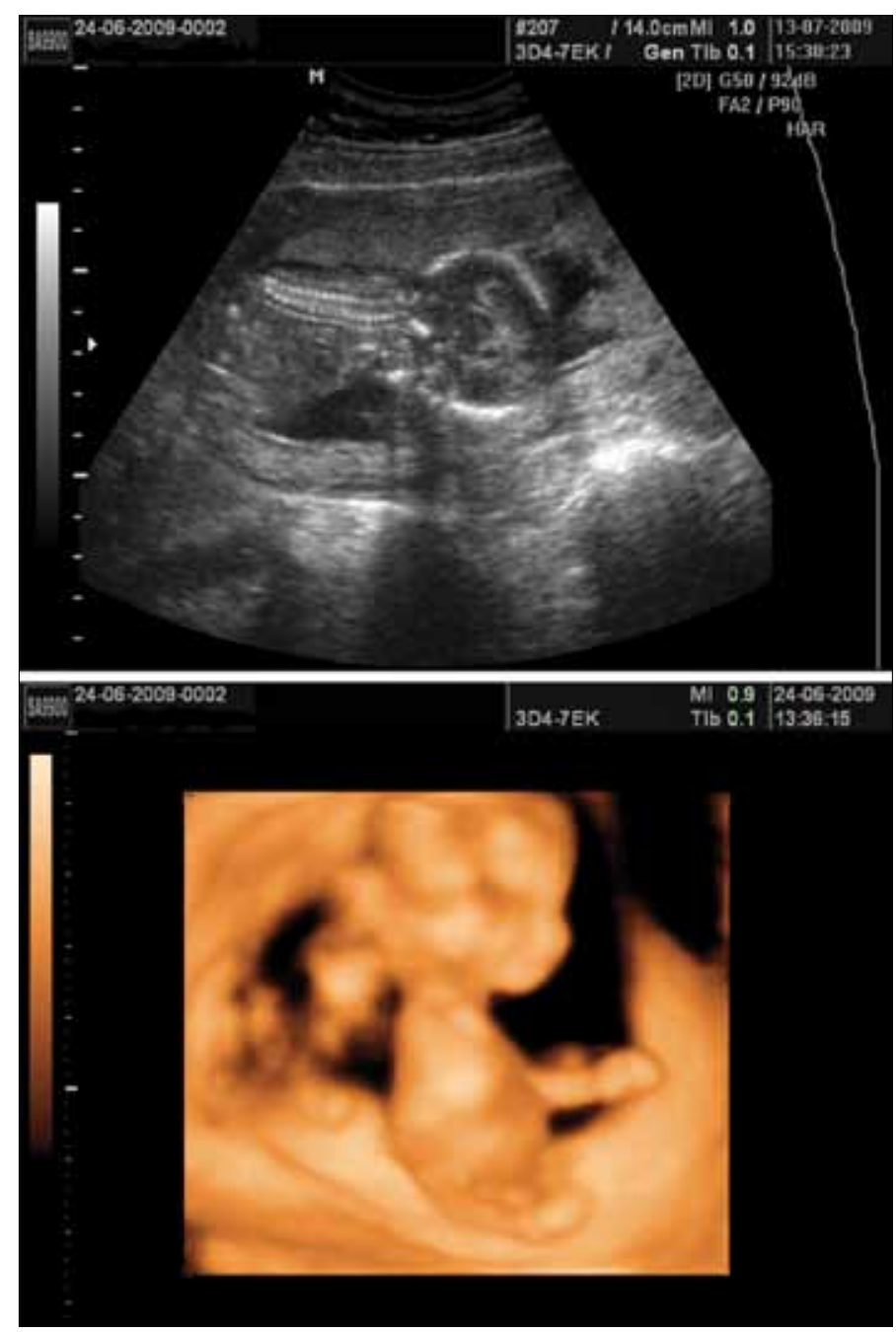

Figure 1 A-B. Vertebral progression was normal until lower thoracic level but after this level neither vertebra nor pelvic bone osssification was observed.

There was no family or patient history of diabetes mellitus. The patient was refered for full ultrasonographic examination with General Electric Voluson 730 Expert and Medison SA 9900 ultrasounds. Ultrasound examinations were carried out both by gray scala and 3D imaging and revealed that the cranium and upper extremities were normal. Vertebral progression was normal until the lower thoracic level, but after this level neither vertebra nor pelvic bone osssification was observed (Figure $1 \mathrm{~A}-\mathrm{B})$. Also, the lower extremities were shorter than expected according to the last menstural period and hips were flexed. Other organ system examinations were unremarkable. The amniotic fluid and placenta seemed normal for gestational age. The couple were informed about the fetus' sonographic findings and probable complications after birth. The couple decided to terminate the pregnancy. After provoked abortus, physical examination of the fetus revealed that the upper portion of the body was normal but the pelvis was atrophic and narrow, abdomen was distended, lower extremities were shorter and legs fully flexed like frog legs. Talipes equinovarus was seen in both feet (Figure 2 A-B).
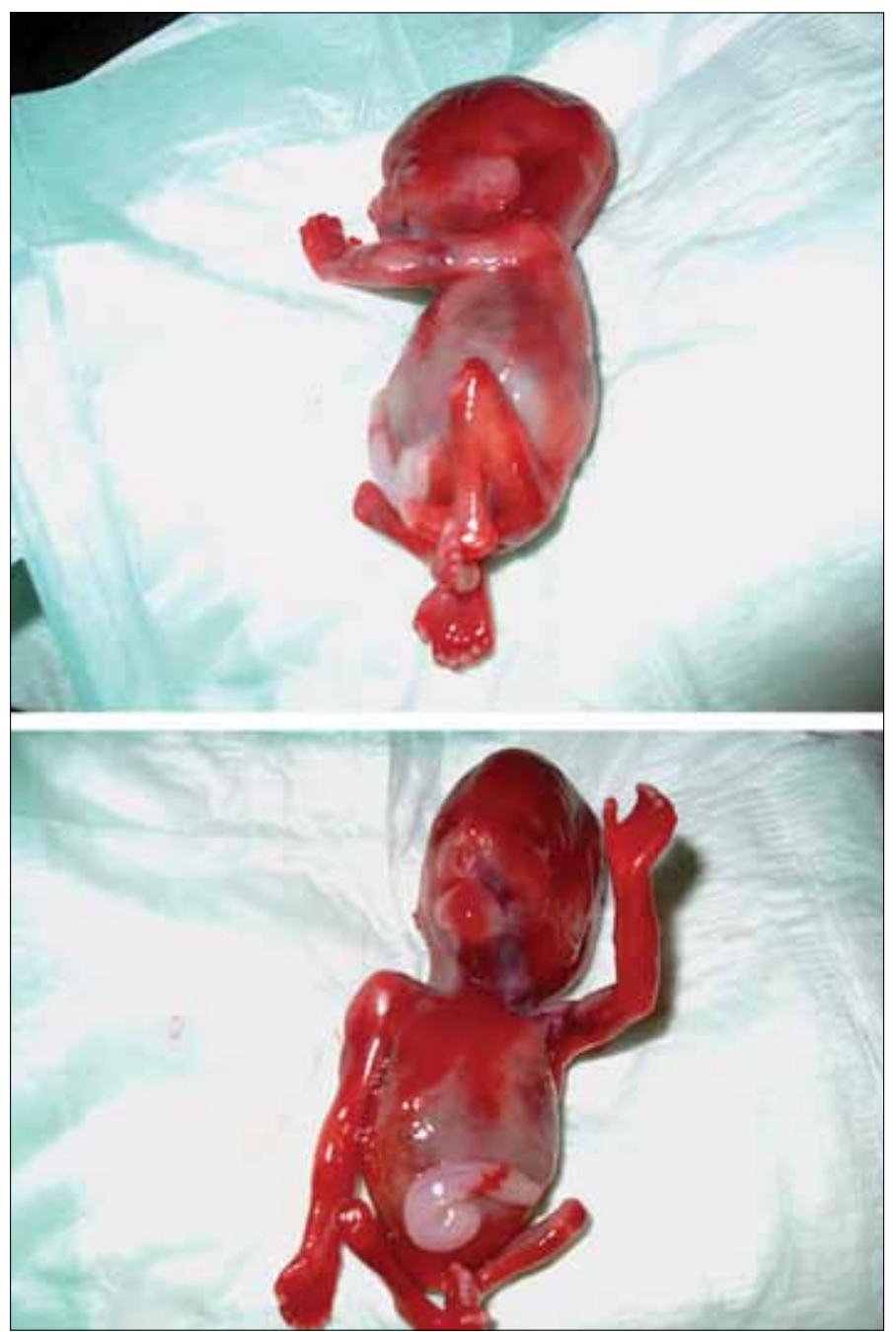

Figure 2 A-B. Talipes equinovarus was seen in both foot

\section{Discussion}

CRS is a syndrome characterized by a series of lower vertebral anomalies that should be associated with pelvic bone deformity. Other than this, some anomalies of the lower limbs, NTD, gastrointestinal tract, genitourinary tract and cardiac organs may accompany the condition (7). In our case, the fetus was seen to have both vertebral, pelvic and lower limb deformities on physical examination.

Although the exact mechanism for this syndrome has not been established, it was thought that there is a defect in the induction of the caudal elements of the embryo before the $28^{\text {th }}$ day of gestational period. The embryologic attack occurs at the midposterior axis of the mesoderm which causes absence of the progression of the mesoblastic caudal bud. Advances in the understanding of axial mesoderm patterning at early gestation reveal that one or more processes of primitive streak migration, primary or secondary neuralization, or differentiation are compromised $(7,8)$. The relationship and interdependence of developing caudal nervous, spinal, hindgut, and mesonephric elements involved in the closure of the neural tube result in the 
development of neural, distal vertebral, anorectal, renal, and genital abnormalities that produce CRS. However, structures that are developmentally distant from these caudal elements, such as the brain, proximal spine, and spinal cord, are not generally involved in CRS (2).

Caudal regression syndrome is a rare disease and the true pathogenesis is unclear. Only 0.1 to 0.25 per 10,000 pregnancies have been complicated with CRS (4). Caudal regression syndrome is thought to occur in up to $1 \%$ of pregnancies in diabetic women. Up to $22 \%$ cases of CRS are associated with type 1 or type 2 diabetes mellitus in the mother. Insulin-dependent diabetic women are 200 to 400 times more likely to have a child with CRS than women without diabetes (3-6). For this reason, CRS is the most characteristic fetal abnormality of diabetic embryopathy (3). However, CRS has also occurred in nondiabetic women with confounding etiologic factors. Genetic factors have been proposed, but the lack of repetition of identical malformations in subsequent pregnancies does not support a genetic hypothesis (9). Also, no apparent enhancement is seen in chromosomal abnormalities.

Padmanabhan's experimental study showed the role of retinoic acid in producing CRS in the mouse fetus (10). Retinoic acid, when given in different dosages to TO mouse fetuses, resulted in CRS in most of the survivors. In another study, exposure of pregnant mice to all-trans retinoic acid, at a time when the metanephros has yet to form, causes failure of kidney development along with caudal regression (11). Drug-related etiology for extreme caudal agenesis in a human fetus has been suggested (12). The mother had used minoxidil solution for hair loss 4 years prior to and during gestation. She also received trimethoprim-sulfamethoxazole during the first trimester for an upper respiratory problem. There was no history of maternal diabetes or familial genetic diseases. All of these studies and cases strongly suggest that various chemicas may play a teratogenic role in the genesis of CRS. In our case, neither diabetes mellitus nor various chemicals were detected. Blood glucose level was under the normal range. The only treatment used before conception was ovulation induction with gonadotrophins because of primary infertility. This suggests that sporadic cases must be kept in mind.

Previously, it was thought that sirenomelia is the severe form of CRS but 1993 Twicker et al. (13) reported the differences of either clinical presentation or etiologic factors for both syndromes. Vascular steal mechanism is suspected for sirenomelia which results in severe ischemia of the caudal spinal segment. Apart from CRS, sirenomelia exhibits more severe caudal dysgenesis, fused lower limbs and renal agenesis that causes fatal progression with oligohydramnios and pulmonary hypoplasia. Our case is distinct from sirenomelia due to normal amniotic fluid volume, separate legs, normal number of lower extremity bones, and presence of normal appearing kidneys.
In conclusion, we described a case of early second trimester fetus with caudal regression syndrome without any known risk factor. Clinicians must keep in mind that CRS may be seen without any risk factors and a small CRL size or incomplete vertebral ossification may be the first signs of the syndrome. Early determination gives the opportunity for termination of pregnancy until we can prevent formation of the new cases by introducing the exact pathogenesis.

\section{Conflict of interest}

No conflict of interest was declared by the authors.

\section{References}

1. Sadler TW. Langman's Medical Embryology. 9th ed. Philadelphia, PA: Lippincott Williams \& Wilkins; 2004; 60-110.

2. Stroustroup-Smith A, Grable I, Levine D. Case 66: caudal regression syndrome in the fetus of a diabetic mother. Radiology. 2004; 230: 229-33.

3. Gabbe SG, Niebyl JR, Simpson JL. Obstetrics: Normal and Problem Pregnancies. 4th ed. New York, NY. Churchill Livingstone; 2002; 1090-1.

4. Cullier F, Charpentier AS, M'Lamali H, Colbert R. Jarcho-Levin syndrome with caudal regression. http://www.thefetus.net. Accessed December 2005; 15

5. Aslan H, Yanik H, Celikaslan N, Yildirim G, Ceylan Y. Prenatal diagnosis of caudal regression syndrome: a case report. BMJ Pregnancy Childbirth. 2001; 1: 8. [CrossRef]

6. Wender-Ozegowska E, Wroblewska K, Zawiejska A, Pietryga M, Szczapa J, Biczysko R. Threshold values of maternal blood glucose in early diabetic pregnancy-prediction of fetal malformations. Acta Obsteitricia et Gynecol Scand. 2005; 84: 17-25. [CrossRef]

7. Zaw W, Stone DG. Caudal regression syndrome in twin pregnancy with type II diabetes. J Perinatol 2002; 22: 171-4. [CrossRef]

8. Twining P, McHugo J, Pilling D. Textbook of fetal abnormalities. Philadelphia, Pa: Saunders, 2000; 158-60.

9. Ogata ES. Carbohydrate homeostasis. In: MacDonald MR, Seshia MM, Mullett MD, eds. Avery's Neonatology, Pathophysiology and Management of the Newborn. 6th ed. Philadelphia, PA: Lippincott Williams \& Wilkins; 2005; 876-91.

10. Padmanabhan P. Retinoic acid-induced caudal regression syndrome in the mouse fetus. Reproductive Toxicoloygy 1998; 12: 139-51. [CrossRef]

11. Tse HK, Leung MB, Woolf AS, Menke AL, Hastie ND, Gosling JA, et al. Implication of Wt1 in the Pathogenesis of Nephrogenic Failure in a Mouse Model of Retinoic Acid-Induced Caudal Regression Syndrome.Am J Pathol. 2005; 166: 1295-307. [CrossRef]

12. Singh SK, Singh RD, Sharma A. Caudal regression-case report and review of the literature. Pediatr Surg Int. 2004; 21: 578-81.

13. Twickler D, Budorick N, Pretorius D, Grafe M, Currarino G. Caudal regression versus sirenomelia: sonographic clues. J Ultrasound Med 1993; 12: 323-30. 